\title{
Het onzichtbare zichtbaar maken
}

\author{
Citation for published version (APA):
}

de Windt, L. J. (2011). Het onzichtbare zichtbaar maken. Maastricht University.nl. https://doi.org/10.26481/spe.20110101lw

Document status and date:

Published: 01/01/2011

DOI:

10.26481/spe.20110101/w

Document Version:

Publisher's PDF, also known as Version of record

\section{Please check the document version of this publication:}

- A submitted manuscript is the version of the article upon submission and before peer-review. There can be important differences between the submitted version and the official published version of record.

People interested in the research are advised to contact the author for the final version of the publication, or visit the DOI to the publisher's website.

- The final author version and the galley proof are versions of the publication after peer review.

- The final published version features the final layout of the paper including the volume, issue and page numbers.

Link to publication

\footnotetext{
General rights rights.

- You may freely distribute the URL identifying the publication in the public portal. please follow below link for the End User Agreement:

www.umlib.nl/taverne-license

Take down policy

If you believe that this document breaches copyright please contact us at:

repository@maastrichtuniversity.nl

providing details and we will investigate your claim.
}

Copyright and moral rights for the publications made accessible in the public portal are retained by the authors and/or other copyright owners and it is a condition of accessing publications that users recognise and abide by the legal requirements associated with these

- Users may download and print one copy of any publication from the public portal for the purpose of private study or research.

- You may not further distribute the material or use it for any profit-making activity or commercial gain

If the publication is distributed under the terms of Article $25 \mathrm{fa}$ of the Dutch Copyright Act, indicated by the "Taverne" license above, 
Mijnheer de Pro-Rector

Decaan van de Faculteit health, Medicine and Life Sciences

Gewaardeerde collega's

Lieve familie en vrienden,

Geachte toehoorders.

Een lange tijd heb ik getwijfeld hoe ik deze rede zou beginnen, maar het leek me uiteindelijke gepast te beginnen bij een voor mij relevant begin.

Curaçao is een tropische eiland, gelegen in het zuidelijk deel van de Caribische zee vlak boven het zuid-amerikaanse vasteland en onderdeel van het Koninkrijk der Nederlanden. Over de oorsprong van de naam Curaçao bestaan verschillende theorieën. Een gangbare verklaring is dat het is afgeleid van het Portugese woord voor 'hart' (coração), wat zou verwijzen naar het eiland als een centrum van handel. Een andere uitleg is dat de naam een afgeleide is van het portugese of spaanse werkwoord voor "genezen", "cura". Een combinatie van beide verklaringen lijkt mij wel gepast voor dit betoog.

Een laatste uitleg is dat Curaçao verwant is met de naam die de oorspronkelijke inwoners gebruikten om zichzelf mee aan te duiden. Het eiland werd inderdaad al 2500 jaar voor Christus bewoond door de originele inheemse bevolking, Caquetios, onderdeel van de natie van Arawakken, die leefden van kleinschalige verbouw van cassave, visserij, het verzamelen van schelpdieren, en van jacht op klein wild. Daarnaast dreven zij handel met Indianen van andere eilanden en met het vasteland. De nalatenschap van de originele bevolking is nog altijd zichtbaar in de vorm van kleurrijke rotstekeningen en aardewerk kunstvoorwerpen verspreid over de benedenwindse eilanden. Ook is er toenemend bewijs dat de culturele nalatenschap van de inheemse bevolking zich veel verder strekte en een actieve invloed heeft gehad op de meer recentere historie in de vorm van landschap inrichting, landbouw technieken en de latere gesproken talen op het eiland. ${ }^{1}$

$\mathrm{Na} \pm 3$ millenia bewoning door de inheemse bevolking, werd Curaçao in 1499 op 26 juli "ontdekt" door de Spanjaard Alonso de Ojeda. De Spanjaarden vestigden zich definitief rond 1527, en hielden zich vooral bezig met veehouderij, maar omdat de opbrengsten van de Curaçaose agricultuur teleurstellend waren, de zoutpannen geen hoge opbrengst hadden en vooral omdat er geen edelmetalen te vinden waren, doopten de Spanjaarden de benedenwindse eilandengroep tot "islas inutiles", nutteloze eilanden. De reden voor de inval en verovering van het eiland in 1643 door de Nederlandse West-Indische Compagnie, lag in het feit dat de WIC op zoek was naar een uitvalsbasis voor handel en kaapvaart. Curaçao lag namelijk gunstig ten opzichte van de Spaanse koloniën op het vasteland en had de beste natuurlijke haven tot dan toe bekend in het Caraïbisch gebied.

Al snel startte de WIC zeer actief met de handel in slaven afkomstig uit de Westelijke kustgebieden van Afrika, en ontstond de belangrijkste regionale slavenmarkt, vanwaar europese koloniën in Noord, Midden en Zuid-Amerika voorzien werden van goedkope arbeid. De WIC maakte Curaçao in 1674 tot vrijhaven en verkreeg hierdoor een sleutelpositie in de internationale handelsnetwerken. De WIC leverde slaven tegen zeer scherpe prijzen en concurreerde zo de Engelse, Franse en Portugese handelaren de markt uit. Een relatief klein deel van de aangekomen Afrikanen bleef achter op Curaçao waarvan de meeste terecht kwamen op een van de plantages die gebouwd werden rond karakteristieke en luxueuze landhuizen waar

\footnotetext{
${ }^{1}$ Charles C. Mann. 1491: New Revelations of the Americas Before Columbus. Knopf. 2005
} 
indigo, katoen, tabak, sorghum en suikerriet verbouwd werd. De slaven ontwikkelde een blijvende invloed uit op verschillende aspecten van de nieuwe samenleving, waaronder de kunst, agricultuur, taal, omgangsvormen en muziek. De vrije handelsgeest en economische voorspoed leidde tot een continue immigratie vanuit de buurlanden maar ook van Aziaten, Arabieren en Sefardische joden, die zich vestigden en bijdroegen aan de culturele diversiteit van de bevolking. Dus, daar waar de Spanjaarden twee eeuwen eerder het eiland nog als nutteloos bestempelden, zorgde de economische impuls in de vorm van goedkope arbeidskrachten, een open geest en diversiteit, van Curacao in de 17 e eeuw een van de welvarendste eilanden in het Caraïbisch gebied, een welvaart waarvan het Europees deel van het Koninkrijk van mee profiteerde en de aanzet gaf tot de start van de Gouden Eeuw van het Koninkrijk der Nederlanden.

$\mathrm{Na}$ de afschaffing van de slavernij in 1863 (de economische impuls van goedkope arbeidskrachten stopte abrupt) raakte de economie in het slop. Het economische tij keerde in 1914 toen aardoliereserves in Venezuela werden ontdekt. Shell vestigde meteen een olieraffinaderij op het eiland, waardoor Curacao tijdens de Tweede Wereldoorlog een belangrijke rol bij de levering van brandstof voor de geallieerde troepen. In de jaren veertig en vijttig bracht de economische impuls van de raffinaderij en offshore activiteiten grote welvaart en modernisering voor het eiland, welke weer abrupt stopte na het vertrek van Shell in de jaren tachtig. Curaçao is nog altijd bezig zich uit deze recessie los te worstelen en leeft thans deels van offshore handel, olieraffinage, en toerisme.

Te midden van deze historisch turbulente tijden, voer de in 1684 geboren Jan Willem de Windt op 26 jarige leeftijd als opperchirurgijn van de WIC vanuit Rotterdam naar het eiland Curacao. De nakomelingen van de Windt breidde zich snel uit en na strategische huwelijken met hier eerder gevestigde families, zoals die van baron Andries de Lannoy, kreeg de familie al snel vele plantages en landhuizen op het eiland in bezit. Mijn beide grootvaders, Leon Frederik de Windt en Jan de Wit, vormde de basis voor een herstel van de eerdere connectie met Rotterdam drie eeuwen later. De familie van mijn moeders zijde, getekend door de gruwelen van de Tweede Wereldoorlog, representeert de Nederlandse zijde van mijn achtergrond, een nog altijd verzuilde samenleving waar een open geest, efficiëntie en noeste arbeid hoog in het vaandel staan.

Deze linguïstische, raciale en culturele diversiteit heeft een onuitwisbare invloed gehad op mijn vorming als mens en wetenschapper. Vanuit dit startpunt ontwikkelde ik een voorliefde voor natuurwetenschappen en met name het hart als wetenschappelijke onderzoeksfocus, en meer in het bijzonder, de ziekten van de hartspier.

Het menselijke hart is een holle spier met vier afzonderlijke, door kleppen gescheiden kamers die samen twee pompen vormen die een in serie geschakelde, maar verder gescheiden long- en een lichaamscirculatie op gang houden. In de wand van de rechter boezem zit een klein gebiedje $(1-2 \mathrm{~mm})$ van aangepaste spiercellen, die zorgen voor een elektrische prikkel die zich snel verspreid over het hele hart, wat leidt tot instroom van het ion calcium binnen de hartspiercellen, die een samentrekking veroorzaakt van de hartspiercellen tijdens de systole fase. Tijdens de relaxatie periode wordt het ion calcium actief de hartspiercel uitgewerkt, waardoor de holle spier zich weer kan vullen met bloed uit de longen en de circulatie. Het hart is dus een holle spier die door zich samen te trekken bloed door het lichaam pompt, dit ongeveer eenmaal per seconde doet en maar liefst 5 liter per minuut onvermoeibaar kan uitknijpen, 24 uur per dag, een heel mensenleven lang. Dit feit is des te meer indrukwekkend wanneer we beseffen dat hartspiercellen een 
mensenleven lang meegaan, met andere woorden, ruwweg het aantal cellen die we als jong volwassene verkrijgen worden niet vervangen zoals dat wel plaatsvindt in andere organen.

Het is waarschijnlijk door de combinatie van dit laag regeneratieve vermogen van de hartspiercel, een toenemende levensverwachting en een ongezonde levensstijl, dat ziekten van het hart relatief veel voorkomen in onze samenleving. In deze afbeelding ziet $\mathrm{u}$ het percentage doodsoorzaken van de Nederlandse bevolking in 2009 opgesplitst naar de meest voorkomende aandoeningen. $U$ kunt zien dat zowel voor mannen als vrouwen, cardiovasculaire aandoeningen (in rood gekleurd) een zeer algemeen voorkomende doodsoorzaak is, op de voet gevolgd door kwaadaardige vormingen (in de volkmond ook wel kanker genoemd), en in veel mindere mate ziekten van het ademhalingssysteem, neurologische afwijkingen en afwijkingen in de afweer.

Een van de snelst groeiende cardiovasculaire aandoeningen is hartfalen. Hartfalen is een chronische ziekte waarbij het hart niet meer in staat is om voldoende bloed uit te pompen om aan de behoeften van de weefsels te voldoen. De klassieke oorzaken van hartfalen zijn een langdurige hoge bloeddruk, eerdere hartaanvallen als gevolg van kransslagader verstoppingen, defecten van de hartkleppen of ritmestoornissen, vaak nog verergerd door de aanwezigheid van metabole aandoeningen zoals diabetes. Chronisch hartfalen is momenteel een van de meest voorkomende oorzaken van kostbare ziekenhuisopnames en de vooruitzichten voor de patiënt zijn op langere termijn meestal vrij slecht. Als de oorzaak niet kan worden behandeld (bijvoorbeeld door vervanging van een hartklep) is de levensverwachting statistisch gezien maar enkele jaren - slechter dus dan bij de meeste vormen van kanker. De huidige medicamenteuze behandeling is palliatief, gericht op de verlichting van symptomen en behelst zelden volledige genezing. Momenteel leiden miljoenen Amerikanen en Europeanen, waaronder 240.000 Nederlanders, aan deze aandoening en met het huidige tempo van de vergrijzing in de Westerse wereld zal dit aantal in de toekomst alleen maar toenemen.

Met zo'n relevant klinisch, economisch en maatschappelijk probleem in onze samenleving, ligt het in de lijn van verwachting dat cardiovasculair wetenschappelijk onderzoek van alle aandachtsgebieden in de natuurwetenschappen ook de meest innovatieve en veelbelovende vooruitgangen zal boeken. Niets is minder waar. In deze afbeelding ziet $u$ de aankondiging van een prestigieus wetenschappelijk congres in Engeland, waar wetenschappers van verschillende aandachtsgebieden van vaak voorkomende menselijke ziekten al 5 jaar op rij elkaar jaarlijks informeren over doorbraken in hun vakgebied. Het meest interessante van deze aankondiging is de volledige afwezigheid van cardiovasculaire ziekte als aandachtsgebied, terwijl doorbraken op het gebied van kanker en infectieziekten breeduit zullen worden besproken in dit internationale gezelschap van wetenschappers.

Het nieuws dat geschetst wordt vanuit grote farmaceutische bedrijven is nog minder rooskleurig. Hier ziet u de meest recente zogenaamde "drug pipeline", nog nieuw op de markt te brengen geneesmiddelen op gebied van cardiovasculaire ziekten van het bedrijf van Pfizer, een van de grootste farmaceutische bedrijven ter wereld die, naar eigen zeggen, het meest investeren in onderzoek en ontwikkeling van nieuwe medicijnen. Wat opvalt in deze pijplijn is de volledige afwezigheid van nieuwe medicamenten in de komende jaren voor dit zeer relevante klinische probleem. Slecht nieuws dus voor patiënten met hartfalen.

Een mogelijke oorzaak achter deze afwezigheid van nieuwe innovatieve medicijnen voor cardiovasculaire aandoeningen is het feit dat grote farmaceutische bedrijven al 
jarenlang nog geen 10\% van hun omzet terug investeren in onderzoek en ontwikkeling voor het vinden van nieuwe innovatieve medicijnen (de groene lijn), en gemiddeld een factor 3 meer uitgeven aan marketing en sales (de blauwe lijn), dus het reclame maken en het stimuleren van de verkoop van bestaande medicijnen. Nieuwe medicijnen tegen hartziekten zijn voorlopig dus niet te verwachten vanuit grote farmaceutische bedrijven. Zoals gezegd: slecht nieuws voor patiënten met hartaandoeningen.

Als we dus al innovatie op cardiovasculair gebied kunnen verwachten, dan zal dit moeten komen van academische instellingen als Universiteiten die als deel van het hoger onderwijs volledig gefinancierd worden door de overheid, publiek geld dus. Het spreekt voor zich dat hoe meer een land slim investeert in zijn eigen onderwijs en onderzoek, dit uiteindelijke ten goede zal komen aan het opleidingsniveau en mogelijke nieuwe innovatieve doorbraken op wetenschappelijk gebied.

Hoe is het eigenlijk gesteld met de financiering van onderwijs en onderzoek als stimulans van innovatie in de wereld? Op deze wereldkaart zijn de individuele landen te zien, maar nu gecorrigeerd in grootte naar verhouding van hun overheidsinvestering op gebied van onderwijs en wetenschappelijk onderzoek. Wat gelijk opvalt is de rare vorm van de continenten die de ongelijkheid reflecteren waarin ieder continent investeert in hun onderwijs systeem, waarbij de bulk van investering blijkt te komen van het noordelijk halfrond, met als onbetwiste koplopers de Verenigde Staten in blauw, Europa in het roze en Japan paarsgekleurd. Het zuid Amerikaanse continent, Afrika, en Australie investeren relatief weinig.

Zoemen we nou verder in op de situatie in Europa, dan zien we in de volgende grafiek de individuele investering in hoger onderwijs en onderzoek per land uitgedrukt als percentage van het bruto nationaal product, het collectieve inkomen van een land. Als onderdeel van het verdrag van Lissabon, het verdrag dat Nederland in een referendum massaal had afgewezen, hebben de individuele lidstaten van de Europese Unie in 2007 afgesproken dat elke lidstaat minimaal 3\% van zijn BNP dient te begroten voor onderwijs en onderzoek om zo de competitieve kracht van Europa te vergroten. $U$ kunt zien dat op een paar Scandinavische uitzonderingen na, geen enkel land deze doelstelling momenteel bereikt. Japan, Zwitserland en de Verenigde Staten halen wel deze doelstelling, maar deze landen behoren niet tot de EU. Binnen dit lijstje staat Nederland zeker niet onderaan en scoort iets hoger dan het europees gemiddelde, maar haalt zeker niet de eigen gestelde doelstelling.

Binnen de overheidsinvesteringen in onderwijs en onderzoek gaat uiteraard slechts een deel van de begroting naar universitaire instellingen (de blauwe balk in de grafiek), wat momenteel $0.4 \%$ van ons BNP bedraagt. Ook hier scoort Nederland niet slecht, maar presteert nog altijd ondergemiddeld, haalt zijn eigen doelstellingen niet en moet Zwitserland en de Scandinavische landen voor zich laten in ambitieniveau.

Voldoende financiering is één punt, maar zeker niet het enige ingrediënt voor ware vernieuwing. Ook individuele innovatie is van cruciaal belang. $\mathrm{Er}$ is consensus dat de Nobel prijs een erkenning is voor een werkelijk vernieuwend concept dat de wetenschap en de mensheid als geheel een stukje in de goede richting duwt. Laten we eens kijken hoe het gesteld is met de individuele kwaliteit van de Nederlandse cardiovasculaire wetenschapper waarbij we de Nobelprijs als benchmark nemen. Inderdaad is de Nobelprijs wel ten dele gevallen aan Nederlands cardiovasculair onderzoek, het is alleen jammer dat we zo ver terug in de tijd daarvoor moeten gaan. Bijna 90 jaar terug ontving de in Java geboren Willem Einthoven de Nobelprijs voor de Fysiologie of Geneeskunde als uitvinder van de snaargalvanometer, waarmee hij 
praktisch bruikbare elektrocardiogrammen (ECG) kon vervaardigen. Hij ontwikkelde ook de terminologie voor het interpreteren ervan. Het ECG is tot op de dag van vandaag een belangrijk medisch diagnostisch instrument voor het bepalen van de conditie van het hart. Uiteraard zijn er sinds 1924 nog wel een 6-tal Nobel prijzen uitgedeeld aan cardiovasculaire wetenschappers, maar die zijn bijna zonder uitzondering toegekend aan Amerikaanse wetenschappers.

Als de Nobel prijs een stapje te hoog is, dan zijn er misschien Europese prijzen te identificeren die gegeven worden aan excellente toponderzoekers en die een goede voorbode geven voor een toekomstige Nobel prijs. Eén zo'n europees orgaan is de European Research Council of ERC, een financieringsorgaan voor individuele wetenschappers die in 2007 in het leven werd geroepen door de EU in navolging van het zeer succesvolle overheidsorgaan van de Verenigde Staten, de National Institutes of Health $(\mathrm{NIH})$ dat al vlak na de Tweede Wereldoorlog werd opgericht. Het uitzonderlijke succes van dit Amerikaanse systeem, wat sinds de Tweede Wereldoorlog leidde tot een explosie van Amerikaanse innovatie en Amerikaanse hegemonie op onderzoeksgebied, deed de Europese Commissie doen besluiten het ERC in het leven te roepen. In het ERC systeem kunnen senior onderzoekers tot 2.5 milljoen euro financiering vragen voor hun eigen salariëring, die van hun personeel en de onkosten van het uitvoeren van onderzoek, alles op basis van een goed uitgewerkt onderzoeksvoorstel en het uitvoeren van excellent en innovatief onderzoek. In 2008 werden de eerste ERC Advanced Grant winnaars bekend gemaakt, stuk voor stuk zeer innovatieve Europese toponderzoekers en die heb ik opgesplitst naar hun aandachtsgebied. $U$ kunt zien dat van de 100 prijswinnaars het gros hun sporen hadden verdient en onderzoek deden naar basaal biologische vraagstukken. Er zijn relatief ook veel excellente oncologen, immunologen en neurowetenschappers. Als hekkensluiter komt het cardiovasculaire aandachtsveld naar voren met een schamele 3\% goedkeuring, waarbij alle drie de toponderzoekers ook nog eens niet uit Nederland stammen. Ik bespaar $\mathrm{u}$ het beeld van de opvolgende jaren 2009 en 2010, want ook daar scoorde cardiovasculair onderzoek zeer povertjes, dan niet nog slechter dan het voorafgaande jaar, met slechts 1 goedgekeurd onderzoeksvoorstel in elk jaar. En in beide gevallen gingen die prijzen naar niet-Nederlandse onderzoekers, eenmaal een onderzoeker met de Zwitserse nationaliteit, en eenmaal die met de Finse nationaliteit. Toevalligerwijs net die landen die meer investeren in hun hoger onderwijs en onderzoek.

Misschien dat Europese competitie iets te hoog gegrepen is en moeten we de innovatie op cardiovasculair onderzoeksgebied alleen binnen Nederland analyseren. Ons grootste en goed presterende orgaan dat al tientallen jaren zorgdraagt voor onderzoeksfinanciering voor alle aandachtsgebieden (van chemie tot en met medisch onderzoek) is de Nederlandse Organisatie voor Wetenschappelijk Onderzoek (NWO). De hoogst haalbare prijs voor een academicus in Nederland is de Spinoza prijs, genoemd naar Baruch Spinoza, de beroemde $17^{\mathrm{e}}$ eeuwse Nederlandse filosoof, zoon van Portugees-Joodse immigranten. Deze Spinoza prijs wordt binnen Nederland gezien als de bekroning op het werk van jarenlang baanbrekend onderzoek en wordt daarom ook wel als de Nederlandse Nobelprijs aangeduid. Ik heb voor $\mathrm{u}$ alle Nederlandse Spinoza prijswinnaars in de categorie levenswetenschappen op een rijtje gezet, waartoe cardiovasculair onderzoek toebehoort, beginnend met de meest recente prijswinnaars. Wat meteen opvalt is de frequente aanwezigheid van neurowetenschappers, immunologen, oncologisch onderzoekers en vooral weer basaal wetenschappelijke biologen en genetici. Sinds 1995 ontving alleen prof. Frits Rosendaal deze prijs voor zijn baanbrekend werk op het gebied van bloedstollingsfactoren. Dat is dus slechts 1 cardiovasculaire wetenschapper van de 17 wetenschappers sinds 1995. 
Het beeld dat langzaam opdoemt is er een van een afwezigheid van cardiovasculaire ziekte als innovatief aandachtsgebied, terwijl doorbraken in het medisch gebied van kanker, infectieziekten en neurowetenschappen wel degelijk bestaan en breeduit worden besproken in een internationaal gezelschap van wetenschappers. Het geeft mij aan dat het 5 voor twaalf is voor innovatie binnen cardiovasculair onderzoek en dat dit probleem zeker niet alleen in Nederland speelt.

Mijn inziens heeft het cardiovasculair onderzoek in Nederland een inhaalslag te maken en dient zich te richten op 3 kernpunten, 3 ingrediënten om de kwaliteit van onderzoek te verbeteren en meer competitief te maken ten opzichte van de andere medische aandachtsgebieden. Ten eerste innovatie, ten tweede dient nagedacht te worden over het human capital aan onderzoekers, en tot slot dienen financieringsmiddelen doelgericht ingezet te worden.

Als eerste innovatie. Wat verstaan we eigenlijk onder innovatie? Wanneer is een idee baanbrekend en vernieuwend? Welke kenmerken heeft de innovatieve wetenschapper? Historie geeft ons een vele voorbeelden van baanbrekende wetenschappers zoals Galileo Galilei, de Italiaanse natuurkundige, astronoom, wiskundige en filosoof uit de Renaissance. Ook al was hij niet de uitvinder van de telescoop, op grond van zijn waarnemingen van Jupiter's manen en Venus' fasen kwam Galilei tot de conclusie dat de Zon in het midden van ons zonnestelsel staat en niet de Aarde. Ondanks waarschuwingen van collega wetenschappers, bracht zijn koppige stellingname hem in conflict met de conservatieve Katholieke Kerk, die hem uiteindelijke het vonnis van levenslang huisarrest oplegde voor het openbaren van zijn bevindingen. Galileo Galilei is het levende bewijs dat topwetenschappers vaak eerdere ontdekkingen uit andere vakgebieden gebruiken om goede ideeën te genereren, en dat ze opvallend vaak tegendraadse en excentrieke persoonlijkheden zijn die sterke oppositie kunnen ondervinden van conservatieve, behoudende stromingen.

De Amerikaanse socioloog Everett Rogers categoriseerde dit sociologisch fenomeen in zijn bestseller "categories of innovativeness", waarbij hij het menselijk gedrag op innovatie onderverdeelde in classificaties. Ware innovatieve mensen behelsen maar een minieme fractie van de samenleving en staan vaak alleen (Innovators). Gelukkig zijn er wel mensen die een goed idee snel herkennen en dit vroeg adopteren (Early Adaptors), gevolgd door een vroege meerderheid (Early Majority). Pas veel later zal een meer conservatieve meerderheid (Late Majority) zich scharen achter het idee, en helemaal op het laatst en met gezonde tegenzin, de achterblijvers (Laggards).

Het is belangrijk te weten dat de eerste menselijke reactie op het idee en de persoonlijkheid van ware innovators vaak op de lachspieren werkt en tegenstand oproept. Om dit kracht bij te zetten, laat ik u nu een filmpje zien ter illustratie van dit fenomeen.

Op een warme zomerdag bij een meer besloot een jongeman spontaan op te staan en een nieuw dansje uit te voeren, iets helemaal nieuws te doen in deze grote groep van mensen die allemaal zitten. Hij danst zijn curieuze dansje helemaal alleen, en mensen keren zich initieel af van zijn gedrag. Deze man is een voorbeeld van een ware Innovator volgens Everett Rogers' theorie.

Maar al snel krijgt hij medestanders die inzien hoe innovatief en nieuw dit dansje wel niet is, en besluiten hem te volgen in zijn idee. Dit zijn de klassieke Early Adaptors volgens Everett Rogers' theorie. 
Dit kleine gezelschap heeft aantrekkingskracht op een grotere groep mensen (De Early Majority) en het geheel werkt als een kettingreactie, waardoor nu ook de Late Majority zich schaart in het feestgejoel. Zoals u ziet blijven er zelfs dan nog koppige mensen zitten, hoewel er overtuigend bewijs is dat het nieuwe idee hip en vernieuwend is. Dit zijn de Laggards, de achterblijvers, volgens Everett Rogers' theorie. Cardiovasculair onderzoek heeft meer ware innovators en early adapters nodig die nieuwe ideeën in gang durven zetten.

Laten we terug gaan naar het onderwerp van onderzoek. Ons onderzoek heeft zich de afgelopen 12 jaar gericht op het beter begrijpen van de mechanismen van hartspiercel vergrootting, een fenomeen dat zich voordoet in de allereerste fasen bij het ontwikkelen van het syndroom hartfalen. Deze eerste fase van hartspierwand verdikking is nog altijd de sterkste voorspeller of een patiënt in de toekomst hartfalen zal ontwikkelen. Zoals een oncoloog graag de allereerste stappen wil begrijpen hoe een gezonde cel zich plotseling anders gedraagt om uiteindelijk uit te zaaien tot een metastase, en deze eerste stappen nu al de basis vormen van nieuwe innovatieve kanker therapieën, zo denken wij dat een dieper begrip van deze allervroegste ziekteprocessen in het hart cruciaal zullen blijken voor het ontwikkelen van nieuwe therapieën tegen hartfalen.

Om dit proces beter te begrijpen is het duidelijk geworden dat de celkern van de hartspiercel, het celorganel dat onze chromosomen, onze genetische codes bevat, hier aangekleurd met een groen fluorescerende stof, in deze processen een centrale rol speelt. Tot twee decennia geleden werd de rol van het DNA, ons genoom, in het veld van cardiovasculair onderzoek niet eens herkend of erkend.

Al vroeg in mijn carrière besloot ik me volledig te richten op een beter begrip van ons DNA en de invloed die het heeft op cardiovasculaire ziekte. Craig Venter, de excentrieke Amerikaanse bioloog die in 2005 als eerste het volledige humane genoom ontcijferde, refereerde naar DNA als "the only software that builds its own hardware". In dezelfde lijn van gedachte denken wij dat het DNA continu zijn eigen omgeving (de hartspiercel) beinvloedt en daarmee een bepalende rol heeft bij normale homeostase en chronische ziekte. Een goed idee klinkt achteraf altijd erg logisch.

Een moleculair bioloog is getraind om veranderingen in de voor het blote oog onzichtbare processen en bouwstenen binnen in de cel te visualiseren. Daartoe bestaan er verschillende technieken die indirect deze onzichtbare bouwstenen zichtbaar maken. Zo hebben we technieken voor handen om de belangrijkste componenten (DNA, RNA en eiwit) uit de cel te vissen, te scheiden naar grootte en elektrische lading, te transfereren naar speciaal papier en het vervolgens indirect zichtbaar te maken met behulp van lichtgevoelige film. Gewapend met deze moleculair biologische gereedschapskist kunnen we tegenwoordig zelfs individuele moleculen manipuleren in de gekweekte hartspiercel of zelfs in het intacte zoogdier om volledige nieuwe genetische codes en nieuwe organismen te maken om te komen tot een beter begrip hoe ons DNA hartspiercellen gezond houdt of juist ziek maakt.

De basis van moleculair genetische manipulaties heb ik geleerd als zogenaamd postdoctorale onderzoeker tijdens een tweejarig verblijf in een academisch kinderziekenhuis in de stad Cincinnati in de Verenigde Staten in het laboratorium van mijn mentor Jeff Molkentin. Als hoofd van deze afdeling had de moleculair bioloog Jeffrey Robbins als eerste ter wereld hartspier-specifieke genetische codes ontrafeld. Met deze kennis is het momenteel mogelijk om specifiek en alleen het hart van een 
proefdier, in dit geval de laboratorium muis, te kunnen manipuleren zodanig dat we de functie van individuele stukken van het genoom, onze genen, kunnen bestuderen.

Gewapend met deze nieuwe informatie heb ik 5 jaar doorgebracht als startende groepsleider in het Hubrecht Instituut in Utrecht, waar de primaire onderzoeksfocus ligt in de embryologie. Wat mij opviel uit de embryonale ontwikkeling van het hart, is de enorme groeispurt die het hart ondergaat van vroege foetus naar laat embryo, een proces dat mij sterk deed denken aan de groeispurt die het volwassen hart ook ondergaat bij excessieve belasting.

Deze fase in mijn loopbaan heeft inderdaad geleid tot de identificatie en octrooiering van embryonale signalen die participeren aan de pathologische groei van het hart in het volwassen zoogdierhart. Een voorbeeld is het gen "heart and neural crestderivates 2", kortweg Hand2, dat een gespecificeerde en goed gedocumenteerde rol speelt bij het proces van hartontwikkeling in het vroege embryo.

De volgende data zijn nog niet gepubliceerd, dus geachte toehoorders, vandaag heeft $u$ een primeur. Door slim gebruik te maken van de moleculair biologische gereedschapskist, is het ons gelukt om laboratoriummuizen te genereren waarbij we het gen Hand2 alleen in de volwassen hartspiercel kunnen uitschakelen zodat de normale embryonale ontwikkeling niet verstoort raakt. Een dier dat Hand2 mist in het volwassen hart, heeft een normale levenspanne, wat aangeeft dat er geen functie voor het eiwit bestaat in de homeostase van het gezonde volwassen hart. Als we een normaal hart van de laboratoriummuis echter belasten met hoge bloeddruk ontwikkelt het, net als in de mens, pathologische hartspiergroei die snel leidt tot symptomen van hartfalen, gepaard gaande met verbindweefseling en een sterke afname van pompkracht. Het dier dat het eiwit Hand2 niet kon reactiveren, was duidelijk beschermt tegen alle aspecten van hartfaal ontwikkeling. Deze experimenten maken ons duidelijk dat er inderdaad embryonale signalen gereactiveerd worden tijdens het ziekte proces van het hart in de volwassen mens. Het hart grijpt dus terug op zijn vroegste herinnering om het ziekteproces op gang te brengen. Als we zouden kunnen ingrijpen op dit proces, dan zou dit geheel nieuwe therapeutische mogelijkheden kunnen openen voor de behandeling van hartfalen.

Niet alleen embryonale processen worden gereactiveerd in het zieke hart, er bestaan ook signalen in de volwassen hartspier die nauwelijks een rol spelen bij de embryonale ontwikkeling maar die gespecificeerd lijken te zijn voor de groeiprocessen in het volwassen hart. Zo'n intracellulaire signaleringsroute die we bestudeerd hebben bestaat uit een tweetrapsraket, waarbij een calcium-gevoellig enzym, calcineurin, een tweede eiwit, met de afkorting NFAT, naar de celkern kan laten migreren, alwaar het een genprogramma aanzet dat aan de basis van hartfalen ligt.

Wederom gebruik makend van de moleculair genetische gereedschapskist, konden we laboratoriummuizen testen op de ontwikkeling van hartfalen in de aanwezigheid of afwezigheid van het gen en eiwit NFAT. Tot onze verbazing bleken muizen die NFAT missen vanaf de vroegste embryonale ontwikkeling een normaal hart te kunnen ontwikkelen, maar bleken ze opmerkelijk goed bestand tegen overbelasting in de vorm van hoge bloeddruk. Deze proefjes gaven ons het bewijs dat er gespecificeerde en separate signalen en genetische codes bestaan bij de ontwikkeling van hartfalen: aan de ene kant signalen die de hartspier oproept vanuit zijn vroegste embryonale ontwikkeling, en aan de andere kant signalen die alleen in het volwassen hart een functie lijken te hebben. In beide gevallen leidt remming van deze signalen tot protectie tegen hartfaal ontwikkeling. 
In meer recentere jaren hebben we de functie van een klasse van geheel nieuwe moleculen getest in de hartspier. Deze zeer kleine RNA moleculen, die daarom microRNAs genoemd worden, werden begin jaren negentig als eerste ontdekt in planten en blijken in zoogdieren betrokken te zijn bij allerlei medische ziekteprocessen. Deze ontdekkingen hebben een volledig nieuw veld van onderzoek in het cardiovasculaire veld gestimuleerd, mede door de mogelijkheid van technologische mogelijkheden om het stapelen van deze kleine RNA moleculen tegen te gaan met zogenaamde antisense RNA technologie. $\mathrm{Na}$ een onderzoekperiode wat leidde tot de initiële identificatie van een pathologisch microRNA molecuul, hebben wij deze nieuwe antisense RNA technologie succesvol toegepast in laboratorium muizen om de accumulatie van dit RNA molecuul in de overbelaste hartspier tegen te gaan.

De meest indrukwekkende bevinding van dit experiment was dat dieren op dit experimentele medicijn een sterke vermindering vertoonden van pathologische hartspiergroei, een normalisatie van pompkracht en vermindering van verbindweefseling, zelfs in de continue aanwezigheid van overbelasting en zelfs als dieren al in een gevorderd stadium van hartfalen zaten. Omdat de bestaande medicamenten tegen hartfalen niet deze sterke verbetering teweeg brengen, hopen wij in de nabije toekomst deze innovatieve technologie uitgebreid te kunnen testen op veiligheid alvorens het getest kan worden als een volledig nieuwe experimentele therapie in de mens. Vanuit conceptueel oogpunt en op basis van deze gegevens, denken wij dat ook dat de vroeg geactiveerde pathologische signalen die leiden tot een hypertrofie response van de hartspiercel van nature maladaptief zijn en daarmee therapeutische targets voor hartfalen.

$\mathrm{U}$ heeft mij al meerdere keren de term "diversiteit" horen laten vallen. Onder diversiteit verstaan we 'alle aspecten waarop mensen van elkaar verschillen'. Verschillen tussen mensen hebben invloed op hoe zij in hun werk staan. Voor wetenschap is het belangrijk optimaal gebruik te maken van deze verschillen in expertise, opleiding en onderzoekservaring, wat kan bijdragen aan betere resultaten in wetenschappelijke organisaties. Diversificatie heeft zelfs economische voordelen. Het California Public Employees' Retirement System's Investment Committee, de CalPERS, heeft recentelijk de belangrijkste financiele parameters onderzocht van alle bedrijven die in de Fortune 100 genoteerd staan, en vond een directe correlatie tussen de bestuurlijke samenstelling qua geslacht/ethniciteit en bedrijfsprestaties. De bedrijven die relatief meer bestuurders hadden met een diverse achtergrond, presteerden buitengewoon goed op de Dow Jones en de NASDAQ en hadden hogere winsten over een meetperiode van 5 jaar. Het bedrijfsleven maar ookk wetenschappelijke instituties kunnen niet langer competitief zijn in een globaliserende wereld zonder de bestuurlijke laag te diversificeren. Dit gaat hand in hand met een verandering van de samenstelling van de arbeidsmarkt die langzaam steeds diverser wordt in een globaliserende wereld.

Onderzoek is bij uitstek een grensoverstijgend gebied en stopt niet bij landsgrenzen. Onder jongeren zien we ook een vrijwillige drang naar meer grensoverstijgende contacten die vergemakkelijkt worden via sociale media zoals Facebook. Op deze afbeelding herkennen we de contouren van continenten door reeds bestaande Facebook connecties. Nederlandse universiteiten en academische instellingen hebben nog een hele inhaalrace te lopen om de feitelijke diversiteit van de academische arbeidsmarkt ten volle te benutten, vanaf de gelijkwaardige participaties van vrouwen in hoge academische posities tot aan het verzamelen van onderzoekers met diverse technologische opleiding rondom één vraagstuk. Mijn inziens is het bijeenbrengen van een divers pluimage aan wetenschappers in alle bestuurlijke lagen, dé toekomstige uitdaging voor academische instellingen om 
complexe problemen zoals cardiovasculaire ziekten vanuit verschillende invalshoeken te bezien en gezamenlijk op te lossen.

Een lichtend voorbeeld van gerichte financiele stimulatie voor het verzamelen van onderzoekers met een diverse technologische expertise rondom het thema cardiovasculair onderzoek, zijn de Fondation Leducq Translatlantische Netwerken van Excellentie. Deze franse stichting deelt binnen een open competitie jaarlijks aan 3 à 4 teams van internationale toponderzoekers een beurs van 5 miljoen euro uit met als doel innovatieve doorbraken te forceren in dit vakgebied. De competitie voor deze subsidies, die binnen ons vakgebied gezien wordt als één van de meest dan niet meest prestigieuze prijzen, is moordend met slechts een goedkeuringspercentage van 4\%. In 2008 zijn wij in de prijzen gevallen met een ambitieus onderzoeksplan op gebied van de eerder genoemde kleine RNA moleculen. De interacties tussen internationale onderzoekers met uiteenlopende expertises als ontwikkelingsbiologie, farmacologie, cardiologie, chemie en moleculaire biologie, ervaar ik als een openbaring en heeft de kwaliteit van ons onderzoek sterk verbeterd. Dit Leducq Netwerk heeft 2 jaar na de start nu al 37 publicaties in wetenschappelijke tijdschriften gepubliceerd, waarvan 13 in de allerhoogste tijdschriften zoals Nature, Cell en Science. De recente hervormingen van de Nederlandse Hartstichting, met een jaarlijks budget dat groter is dan die van de Fondation Leducq, om hun subsidiebeleid aan te passen binnen het CVON via stimulatie van consortia vorming rondom 1 thema en waarbij de nadruk ligt op fundamenteel onderzoek, vertoont enige gelijkenissen met de strategie van Fondation Leducq, en dit initiatief kan alleen maar worden toejuicht.

Tot slot toch nog eindigend met een optimistische noot: een relatief recent initiatief (gestart in 2003) is de zogenaamde Veni-Vidi-Vici vernieuwingsimpuls, genoemd naar de befaamde Latijnse uitspraak van Julius Caesar "ik kwam, ik zag en ik overwon", waarmee de Nederlandse Organisatie voor Wetenschappelijk Onderzoek jong wetenschappelijke talent wil stimuleren om te komen met vernieuwende onderzoeksconcepten. In deze open competitie biedt de Veni-subsidievorm pas gepromoveerde onderzoekers de mogelijkheid om gedurende drie jaar hun ideeën verder te ontwikkelen. De Vidi subsidievorm van 800.000 euro voor een periode van 5 jaar is gericht op de onderzoeker die na zijn/haar promotie al een aantal jaren onderzoek op postdocniveau heeft verricht en daarbij heeft aangetoond vernieuwende ideeën te genereren. De Vici-subsidievorm is gericht op de ervaren senior-onderzoeker en ontvangt daarvoor een subsidie van max. 1.5 miljoen euro voor een periode 5 jaar, net zoveel als een Spinoza prijs dus. Uit eigen ervaring als 2003 Veni laureaat en 2007 Vidi laureaat 2007 kan ik beamen dat deze subsidievormen cruciale stimulansen zijn geweest tijdens mijn carrière. Binnen onze onderzoeksschool aan de Universiteit Maastricht zijn er momenteel maar liefst 9 Veni, 12 Vidi en 1 Vici beurzen door voornamelijk jonge cardiovasculaire onderzoekers in de wacht gesleept, een feit waar de Universiteit Maastricht terecht fier op mag zijn en daarmee een unieke positie verwerft binnen het cardiovasculaire onderzoeksveld in Nederland. Het ligt in de lijn der verwachting dat op zijn minst een aantal van deze jonge talenten in de toekomst een Vici-beurs zullen binnenhalen. Als deze trend zich doorzet, dan belooft de toekomst een stuk rooskleuriger te worden voor het Nederlandse cardiovasculaire landschap en waarin de Universiteit Maastricht hopelijk daarin een centrale positie wil nemen.

Tot slot een woord van dank.

"Nanos gigantium humerus incidentes", "If I have seen a little further it is by standing on the shoulders of Giants" is de beroemde Latijnse uitspraak uit de mond van de 
$17^{\mathrm{e}}$ eeuwse wetenschapper sir Isaac Newton, een Engelse natuurkundige, die waarschijnlijk het meest bekend is door zijn beschrijving van de zwaartekracht.

Ten eerste wil ik het bestuur van de Stichting Wetenschapsbeoefening UM, het bestuur van CARIM en de decaan van de faculteit van Health, Medicine en Life Sciences bedanken voor het in mij gestelde vertrouwen.

Dank aan Marc van Bilsen, Ger van der Vusse en Rob Reneman die geduldig mij als jonge promovendus de beginselen van wetenschappelijk onderzoek hebben geleerd. Ik heb veel te danken aan mijn Amerikaanse collega's, in het bijzonder Jeff Molkentin. Pieter Doevendans speelde altijd de rode draad in mijn carriere, gaf op cruciale momenten wijze raad en verklapte me ooit dat hij trots zou zijn als ik hoogleraar zou worden. Ook dank aan Hans Clevers en Ronald Plasterk die me de ruimte gaven een onafhankelijke onderzoeksgroep te starten in het Hubrecht Instituut, en zorgde voor de transitie naar academische ziekenhuizen, eerst het UMCU, dank aan mijn collega's aldaar, en uiteindelijk in Maastricht. Ik ben Harry Crijns zeer dankbaar voor zijn warme welkom op zijn afdeling Cardiologie en ik hoop nog vele jaren van zijn afdeling deel uit te kunnen maken. De collega's Stephane Heymans en Paul Volders en alle leden van de onze onderzoeksafdeling ben ik dagelijks dankbaar voor hun energie en positivisme. Een speciale dank aan Mat Daemen en Martin Paul, die de drijvende krachten waren achter mijn komst naar Maastricht. $\mathrm{Na}$ het recente vertrek van Mat Daemen, de beste directeur die ik ooit mee heb mogen maken, ben ik benieuwd hoe onze paden in de toekomst weer zullen kruisen. Uiteraard ook dank aan alle samenwerkende collega's in binnen en buitenland voor hun hulp en concurrentie die me scherp houdt.

Een speciaal woord van dank aan alle vroegere en huidige leden van mijn onderzoeksgroep.

Alle analisten, mensen als Chiel de Theije, Roel van der Nagel, Jenny Meerding, Natasja Kisters, Nicole Bitch en Serve Olieslagers, die met hun expertise de fundamenten maakten waarop verder gebouwd kon worden. Dank aan Barbara Przybylski, een uitmuntend secretaresse.

De eerste lichting jonge promovendi die uitstekend werk hebben geleverd, Eva van Rooij, Vanessa van Empel, Ralph van Oort, Meriem Bourajjaj en Hamid el Azzouzi. De tweede en huidige lichting promovendi waar ik net zoveel van verwacht, Leonne Philippen, Stefanos Leptidis, Kanita Salic, Monika Gladka.

Ik ben zeer dankbaar aan de senior onderzoekers, de postdocs, Meriem Bourajjaj, Gustavo da Silva, Virginie Kinet, Hamid el Azzouzi, Anne Bertrand, Anne-Sophie Armand en Paula da Costa Martins, die met veel energie en hun unieke persoonlijkheden de kwaliteit van het lab sterk verbeterde. Het is goed om te zien dat deze laatsten stevig aan de weg timmeren om hun eigen onderzoeksgroepen te starten.

Mijn hele familie die altijd voor me klaarstonden en waar ik altijd even mezelf kan zijn, in het bijzonder mijn peetouders Boeis en Bertha de Windt en hun kinderen, Charles en Jane de Windt en hun kinderen. Een speciale dank aan mijn neven Leonard de Windt en Orlando Meulens, waarmee ik eindeloos kan filosoferen en schaterlachen, en die eigenlijk meer broers dan neven zijn. Een dank aan Hendrik de Wit, en Bep en Henny Bloem voor prachtige herinneringen, en mijn neef Hans Bloem, ik wens iedereen zo'n neef toe. Aan mijn schoonouders, schoonzussen en schoonbroertje: masha danki! 
Dank aan alle vrienden waarmee ik ben opgegroeid, in het bijzonder Michel Verschuuren, en alle vrienden van latere tijden, speciaal "hermano" Ingemar Merkies en Roy Pieters. Van al mijn vrienden staat Mohammed Lazaar het dichtst bij mij, een bijzonder mens en filosoof die voor je klaarstaat wanneer het nodig is. Mohammed, je doet je naam eer aan!

Mijn zussen Eveline en Jacqueline die heel wat te verduren hadden met zo'n klein broertje. Ondanks dat mijn moeder fysiek hier niet meer is, voel ik haar aanwezigheid nog elke dag, dus kan ik haar gewoon adresseren. Lieve $\mathrm{Pa}$ en $\mathrm{Ma}$, zonder jullie steun en alle duwtjes in de goede richting, had ik hier nooit kunnen staan. Ik ben trots en blij dat jullie zoon mag zijn.

Lieve Aisha en Leyla, mijn kleine meiden, ik ben enorm trots op jullie en trots dat ik jullie vader mag zijn. Jullie vrolijkheid en humor brengen elke dag een glimlach op mijn gezicht. Lieve Diana, amor di mi bida, dankzij jouw engelengeduld, liefde en continue steun heb ik kunnen bereiken waar ik nu ben.

Ik heb gezegd. 